pISSN: 2442-9791; eISSN: 2715-4181

\title{
Skrining Fitokimia dan Uji Toksisitas Ekstrak dan Fraksi Kulit Batang Kumbou (Artocarpus elastica Reinw. ex Bl) dengan Metode Brine Shrimp Lethaly Test (BSLT)
}

\section{(Phytochemistry Screening and Toxicity Test of Extract and Fraction From Kumbou (Artocarpus elastica Reinw. ex Bl) Merr using Brine Shrimp Lethaly Test)}

\author{
Yamin Yamin ${ }^{1}$, Henny Kasmawati ${ }^{1}$, Lisa Talita Linggi Allo ${ }^{1}$ \\ ${ }^{1}$ Program Studi Farmasi, Universitas Halu Oleo, Kendari, 93232 \\ E-mail: yamin_taeri75@ymail.com
}

\author{
Article Info: \\ Received: 10 March 2020 \\ Accepted: 25 March 2020 \\ DOI: \\ 10.33772/pharmauho.v6i1. \\ 11398
}

Keywords : Kumbou bark (Artocaprus elastic Reinw Ex BI), Brime Shrimp Lethaly Test, LC $_{50}$, toxicity

\begin{abstract}
Kumbou plant (Artocarpus elasticus Reinw ex BI) used as traditionally medicine for treatment dysentery, inflammation and infection with metabolic content flavonoids, fenolic, lipids and sterol. The goals in study to look potential for Kumbou bark toxicity using Brine Shrimp Lethaly Test (BSLT) method. The results showed that both methanol extract and ethyl acetat fraction and water fraction had a toxicity of A. salina with $\mathrm{LC}_{50}$ values $349.829 \mu \mathrm{g} / \mathrm{mL}, 456.223 \mu \mathrm{g} / \mathrm{mL}$ dan $449.895 \mu \mathrm{g} / \mathrm{mL}$ recpectively.
\end{abstract}

Tumbuhan Kumbou (Artocarpus elastica Reinw. ex Bl) secara tradisonal digunakan sebagai obat disentri, peradangan dan infeksi dengan kandungan metabloit seperti fenolik, flavonoid, lipid dan sterol. Penelitian ini bertujuan melihat potensi toksisitas kulit batang Китьоu dengan menggunakan metode Brine Shrimp Lethaly Test (BSLT ). Hasilnya menunjukkan bahwa baik ekstrak methanol maupun fraksi etil asetat dan fraksi air memiliki aktivitas tokisisitas terdahap larva A.salina leach dengan nilai $\mathrm{LC}_{50}$ berturut-turut $349.829 \mu \mathrm{g} / \mathrm{ml}, 456.223 \mu \mathrm{g} / \mathrm{ml}$ dan $449.895 \mu \mathrm{g} / \mathrm{ml}$.

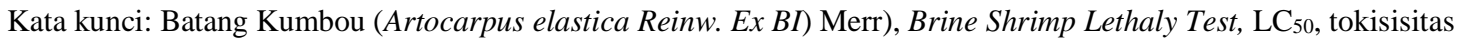

\section{Pendahuluan}

Tumbuhan Kumbou (Artocarpus elastic Reinw. Ex BI) merupakan jenis tumbuhan family Moraceae genus Artocarpus. Secara tradisional bagian buah, akar, daun dan kuncup dapat digunakan dalam pengobatan penyakit demam, sirosis hati, hipertensi dan diabetes [1]. Selain itu, genus ini juga kaya akan metabolit sekunder seperti, flavonoid, khalkon, xanton, triterpen, $\beta$-sitosterol dan arylbenzofuran. Metabolit-tanaman ini diketahui memiliki aktivitas sebagi sitotoksik, antoproliferasi, antiplatelet, antimikroba, antioksidan, antimalaria, dan antiiflamasi [1, 2]. Masyarakat Jawa menggunakan getah A. elastic Reinw. Ex untuk pengobatan penyakit disentri dan antiinflamasi, kulit digunakan untuk kontrasepsi wanita serta daun muda untuk pengobatan tuberculosis-[3]. Selain itu pada kulit batang A. lanceifolius menunjukkan bahwa tumbuhan ini bersifat toksik dan memiliki potensi sebagai antioksidan [4].

Tanaman mengandung senyawa bioaktif, namun pada dosis yang tinggi, semua senyawa bioaktif dapat berpotensi menjadi racun. Oleh karena itu, kekuatan suatu senyawa bioaktif dalam menyebabkan toksik terhadap suatu organisme, dapat menjadi dasar untuk melakukan skrining pada ekstrak maupun fraksi suatu tanaman yang memiliki aktivitas 
biologi. Larva udang Artemia salina L, merupakan salah satu organisme yang dapat dijadikan sebagai bahan uji kekuatan toksik untuk senyawa bioaktif yang berasal dari ekstrak maupun fraksi tanaman. Pengujian kekuatan toksik senyawa bioaktif terhadap larva udang ini dapat menggunakan metode Brine Shrimp Lethaly Test (BSLT) [5].

Penggunaan metode ini disebabkan karena metode ini sangat mudah dan murah, serta mendukung proses awal penentuan efek suatu senyawa. Selain itu, metode ini memiliki korelasi dengan adanya daya sitotoksik berpotensi sebagai anti kanker, anti tumor atau sitotoksik skrining produk alami [6, 7]. Berdasarkan hal tersebut, maka tujuan dari penelitian ini adalah menentukan nilai toksisitas dari ekstrak dan fraksi kulit batang Kumbou (Artocarpus elastic Reinw. Ex BI).

\section{Metode}

\subsection{Sampel Tumbuhan}

Kulit batang Kumbou (Artocarpus elastic Reinw. Ex BI) diperoleh dari Kelurahan Laende, Kecamatan Katobu, Kabupaten Muna, Sulawesi Tenggara. Dideterminasi di Laboratorium Biologi Fakultas Keguruan dan Ilmu Pendidikan Universitas Halu Oleo.

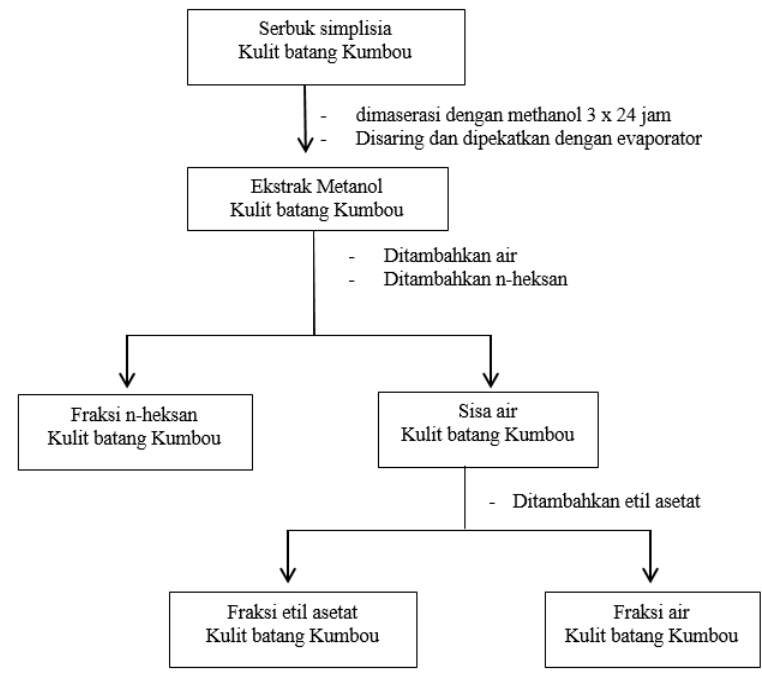

Gambar 1. Skema ekstraksi kulit batang kumbou

\subsection{Ekstraksi}

Sebanyak 600 gram serbuk kulit batang kumbou dimaserasi dengan menggunakan pelarut methanol selama 3 x 24 jam. Pelarut diganti setiap 24 jam, kemudian diuapkan menggunakan rotary evaporator dengan suhu $45^{\circ} \mathrm{C}$ sehingga diperoleh ekstrak kental. Selanjutnya 100 gram ekstrak kulit batang Kumbou dilarutkan dengan aquades, setelah itu dipartisi menggunakan pelarut $n$-heksan dan etil asetat. Hasil partisi kemudian diuapkan dengan menggunakna rotary evaporator, sehingga diperoleh sampel ekstrak metanol, fraksi n-heksan, fraksi etil asetat dan fraksi sisa air. Sebagai mana terlihat pada Gambar 1

\subsection{Skrining Fitokimia}

Skrining fitokimia mengetahui golongan metabolit yang terkandung pada fraksi kulit Kumbou, yakni: senyawa flavonoid, alkaloid, tannin, terpenoi dan saponin

a. Uji Flavonoid

Ekstrakdan fraksi kulit batang Kumbou dimasukan kedalam tabung reaksi sebanyak $1 \mathrm{~mL}$, dimasukan 0,1 gram serbuk magnesium dan ditambahkan $\mathrm{HCl}$ $2 \mathrm{~mL}$ pekat. Terbentuk larutan berwarna merah menunjukan adanya flavonoid

b. Uji Alkaloid

Ekstrak dan fraksi batang Kumbou dimasukan kedalam tabung reaksi $1 \mathrm{~mL}$, lalu ditambahkan pereaksi dragendrof 2-3 tetes Terbentuknya endapan cokelat menunjukkan adanya senyawa alkaloid

c. Uji Terpenoid Ekstrak dan fraksi kulit batang Kumbou dimasukkan kedalam tabung reaksi sebanyak 1 $\mathrm{mL}$, dan ditambahkan $0,5 \mathrm{~mL}$ asam asetat anhidrat dan asam sulfat pekat sebanyak $2 \mathrm{~mL}$. Terbentuknya warna merah atau ungu menunjukkan adanya senyawa terpenoid.

d. Uji Saponin

Ekstrak dan fraksi air kulit batang Kumbou dimasukkan ke dalam tabung reaksi sebanyak 1 $\mathrm{mL}$, ditambahkan dengan $2 \mathrm{~mL}$ air panas kemudian didinginkan, dikocok kuat selama 10 detik. Terbentuk buih yang mantap selama tidak kurang dari 10 menit

e. Uji Tanin

Ekstrak dan fraksi kulit batang Kumbou dimasukkan dalam tabung reaksi sebanyak $1 \mathrm{~mL}$, ditambahkan dengan $1 \mathrm{~mL}$ larutan Fe (III) klorida $1 \%$. Terbentuk warna biru tua, biru kehitaman atau hitam kehijuan menunjukkan adanya senyawa tannin

\subsection{Uji Toksisitas Metode Brine Shrimp Lethaly Test (BSLT)}

Pengujian tokisitas dilakukan berdasarkan metode (Sumihe et al., 2013) dengan sedikit modifikasi Sebanyak 10 larva udang dimasukan kedalam vial uji, kemudian ditambahkan larutan 
sampel hingga volumenya mencapai 5. Setiap konsentrasi dilakukan 3 kali pengulangan. Sebagai kontrol pelarut dilakukan dengan 2,5 mL larutan blanko kemudian ditambahkan air laut 2,5 mL. Pengujiannya dilakukan dengan menggunakan konsentrasi dengan variasi konsentrasi yaitu $10 \mathrm{ppm}$, 100 ppm, 125 ppm , 250 ppm, 500 ppm, 750 ppm, 1000 ppm , 2000 ppm.

\subsection{Analisis Data}

Analisis probit antara konsentrasi sampel dan jumlah kematian larva diuji menggunakan Minitab ver. 18 sehingga menunjukkan nilai $\mathrm{LC}_{50}$ dari masingmasing sampel tersebut. Suatu zat dinyatakan bersifat toksik jika LC50 <1000 $\mu \mathrm{g} / \mathrm{mL}$ untuk ekstrak dan $<30 \mu \mathrm{g} / \mathrm{mL}$ untuk senyawa murni [5].

\section{Hasil dan Pembahasan}

Skring fitokimia ekstrak dan fraksi kulit batang Kumbou (Artocarpus elastic Reinw. Ex BI) menujukkan bahwa ekstrak metanol, fraksi etil asetat dan fraksi air, semuanya positif mengandung alkaloid, flavonoid, tannin, saponin dan terpenoid, sementara pada spesies yang A. lanceifolius ROXB, menurut penelitian sebelumnya, fraksi etil asetat negatif terpenoid, dan pada methanol positif semua [4]. Dimana perbandingan keduanya dapat dilihat pada tabel 1.

Tabel 1. Hasil skrining fitokimia ekstrak metanol dan fraksi etil asetat dan fraksi air kulit batang Kumbou

\begin{tabular}{cccccc}
\hline & \multicolumn{5}{c}{ Sampel } \\
\cline { 2 - 5 } Senyawa & \multicolumn{3}{c}{ Ekstral Metanol } & \multicolumn{2}{c}{ Fraksi etil asetat } \\
\cline { 2 - 5 } Fitokimia & A. elastic & $\begin{array}{c}\text { A lanceifolius } \\
\text { (Hasmindar } \text { et.al., }\end{array}$ & A. elastic & $\begin{array}{c}\text { A lanceifolius } \\
\text { (Hasmindar, } \text { H.al., }\end{array}$ & Fraksi air \\
& & $2019)$ & & $2019)$ \\
Alkaloid & + & + & + & + & + \\
Flavonoid & + & + & + & + & + \\
Tanin & + & + & + & + & + \\
Saponin & & + & + & + & + \\
Terpenoid & + & + & + & + & + \\
\hline
\end{tabular}

Tabel 2. Nilai probit mortalitas ekstrak dan fraksi kulit batang Kumbou terhadap larva Artemia salina

\begin{tabular}{|c|c|c|c|}
\hline Sampel & Konsentrasi (ppm) & \% Mortalitas & $\mathrm{LC}_{50}(\mathrm{ppm})$ \\
\hline \multirow{8}{*}{ Ekstrak metanol } & $10 \mathrm{ppm}$ & $0 \%$ & \multirow{8}{*}{$\mathrm{LC}_{50}=349,829 \mathrm{ppm}$} \\
\hline & $100 \mathrm{ppm}$ & $13,33 \%$ & \\
\hline & $125 \mathrm{ppm}$ & $30 \%$ & \\
\hline & $250 \mathrm{ppm}$ & $53,33 \%$ & \\
\hline & $500 \mathrm{ppm}$ & $63,33 \%$ & \\
\hline & 750ppm & $90 \%$ & \\
\hline & $1000 \mathrm{ppm}$ & $100 \%$ & \\
\hline & $2000 \mathrm{ppm}$ & $100 \%$ & \\
\hline \multirow{8}{*}{ Fraksi air } & $10 \mathrm{ppm}$ & $0 \%$ & \multirow{8}{*}{$\mathrm{LC}_{50}=456,223 \mathrm{ppm}$} \\
\hline & $100 \mathrm{ppm}$ & $7 \%$ & \\
\hline & $125 \mathrm{ppm}$ & $26,66 \%$ & \\
\hline & $250 \mathrm{ppm}$ & $36,66 \%$ & \\
\hline & $500 \mathrm{ppm}$ & $60 \%$ & \\
\hline & $750 \mathrm{ppm}$ & $77 \%$ & \\
\hline & 1000 ppm & $93,33 \%$ & \\
\hline & $2000 \mathrm{ppm}$ & $100 \%$ & \\
\hline \multirow{8}{*}{ Fraksi etil asetat } & $10 \mathrm{ppm}$ & $7 \%$ & \multirow{8}{*}{$\mathrm{LC}_{50}=449,895 \mathrm{ppm}$} \\
\hline & $100 \mathrm{ppm}$ & $20 \%$ & \\
\hline & $125 \mathrm{ppm}$ & $26,66 \%$ & \\
\hline & $250 \mathrm{ppm}$ & $36,66 \%$ & \\
\hline & $500 \mathrm{ppm}$ & $53,33 \%$ & \\
\hline & 750ppm & $77 \%$ & \\
\hline & $1000 \mathrm{ppm}$ & $90 \%$ & \\
\hline & $2000 \mathrm{ppm}$ & $100 \%$ & \\
\hline
\end{tabular}


Metode BSLT merupakan metode pengujian toksisitas yang sangat mudah dan murah, serta mendukung proses awal penentuan efek suatu senyawa yang berpotensi sebagai anti kanker, maupun anti tumor atau sitotoksik skrining dari produk alami. Suatu senyawa dikatakan kurang toksik jika memiliki nilai $\mathrm{LC}_{50}$ kurang dari $1000 \mu \mathrm{g} / \mathrm{L}$ dan akan sangat toksik jika penguran nilai $\mathrm{LC}_{50}$ kurang dari $30 \mu \mathrm{g} / \mathrm{L}$. Pada penelitian ini, digunakna larva udang Artemia salina yang telah berumur 48 jam karena pada umur ini organ A. salina sudang terbentuk sempurna $[8,9]$. Hasil pengujian toksisitas akut ekstrak dan fraksi kulit batang Kumbou dengan menggunakan A. salina dengan konsentrasi sampel 10 ppm, 100 ppm, 125 ppm, 250 ppm, 500 ppm, 750 ppm, 1000 ppm, 2000 ppm terlihat pada tabel 2.

Data yang tersaji pada gambar 2 menunjukkan bahwa baik ekstrak maupun fraksi dari kulit batang Kumbou (A. elastic Reinw BI) bersifat toksik dengan nilai LC50 dari ekstrak methanol (ME), fraksi etil asetat (FE) dan fraksi air (FA) secara berturut-turut sebesar 349,829 $\mu \mathrm{g} / \mathrm{mL}, 456,223 \mu \mathrm{g} / \mathrm{mL}$ dan 449,895 $\mu \mathrm{g} / \mathrm{mL}$, namun hal ini kurang toksik jika dibandingkan dengan A. lenceifolius sebagai mana yang dilaporkan oleh [4], dimana LC50 dari etil asetat sebesar 0,3615 $\mu \mathrm{g} / \mathrm{mL}$ dan metanol sebesar 0,2069 $\mu \mathrm{g} / \mathrm{mL}$.

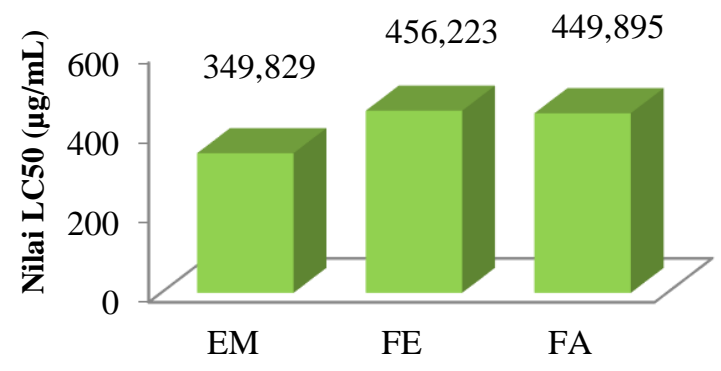

Gambar 2. Nilai LC L $_{50}$ ekstrak methanol (EM), Fraksi etil asetat (FE) Fraksi air (FA)

Semakin kecil nilai $\mathrm{LC}_{50}$ dari suatu sampel, menunjukkan bahwa sampel tersebut semakin bersifat toksik. Gambar 2 menunjukkan bahwa ekstrak methanol memiliki nilai $\mathrm{LC}_{50}$ lebih rendah dibandingkan dengan fraksi air maupun fraksi etil asetat dengan nilai berturut-turut $349,829 \mu \mathrm{g} / \mathrm{mL}$, $456,223 \mu \mathrm{g} / \mathrm{mL}$ dan $449,895 \mu \mathrm{g} / \mathrm{ml}$. Data tersebut menunjukan bahwa crude ekstrak metanol kulit batang Kumbou (A elastic Reinw. Ex BI) lebih toksik dari pada fraksi etil asetat dan fraksi air. Hal ini sejalan dengan penelitian pada sampel Polygala sabulosa. Hal ini dikarenakan masih banyaknya kandungan senyawa metabolit sekunder dalam ekstrak methanol, sehingga memberikan efek sinergi senyawa yang terdapat dalam crude ekstrak tersebut [12]. Suatu sampel dalam bentuk ekstrak dapat dikatakan toksik jika nilai $\mathrm{LC}_{50}$ kurang dari $1000 \mu \mathrm{g} / \mathrm{mL} \quad(<1000$ $\mu \mathrm{g} / \mathrm{mL})$ [6]. Data tersebut menunjukkan bahwa senyawa-senyawa yang paling bersifat toksik dalam kulit batang Kumbou terdapat dalam ekstrak methanol.

\section{Kesimpulan}

Ekstrak methanol, fraksi etil asetat dan fraksi air kulit batang Kumbou (Artocaprus elastic) bersifat toksik pada larva udang A. salina, dengan ekstrak methanol memiliki daya toksik yang lebih kuat dengan nilai $\mathrm{LC}_{50} 349,829 \mu \mathrm{g} / \mathrm{mL}$. Sehingga ekstrak methanol dapat diisolasi lebih lanjut untuk mengetahui senyawa yang paling bersifat toksik dan kemungkinan dapat dikembangkan menjadi obat anti kanker.

\section{Ucapan Terima Kasih}

Ucapan terima kasih kepada Fakultas Farmasi Universitas Halu Oleo atas dukungan dan bantuan dalam pelaksanaan penelitian ini.

\section{Daftar Pustaka}

1. Ramli, F., Rahmani, M., Kassim, N. K., Hashim, N. M., Sukari, M. A., Akim, A. M., \& Go, R. (2013). New diprenylated dihyrochalcones from leaves of Artocarpus elasticus. Phytochemistry Letters, 6(4), 582-585.

2. Jamil, S., Taher, M., Sirat, H. M., \& Othman, N. A. (2012). Flavonoids and triterpenes from the leaves of artocarpus fulvicortex. Natural Product Communications, 7(12), 1587-1588.

3. Musthapa, I., Juliawaty, L. D., Syah, Y. M., Hakim, E. H., Latip, J., \& Ghisalberti, E. L. (2009). An oxepinoflavone from Artocarpus elasticus with cytotoxic activity against P-388 cells. Archives of Pharmacal Research, 32(2), 191-194.

4. Hamsidar H, Nunuk H. Soekamto, Yana M. Syah, F. (2019). Determination Of Secondary Metabolites, Toxicity And Antioxidant Activities Of Bark Extracts Of Artocarpus lanceifolius ROXB.

5. Megawati, Ahmad Darmawan, I. dwiatmi dewijanti. (2012). BIOACTIVITY Brine Shrimp Lethality Test Extract And Fractination From Kalanchoe Pinnata Lam Pers. 147-151.

6. Widiyarti, G., Supiani, S., \& Tiara, Y. (2018). Antioxidant Activity and Toxicity of Puspa (Schima wallichii) Leaves Extract from Indonesia. Journal of Tropical Life Science, 8(2), 151-157. 
7. Mappasomba, M., Wirasmanto, B., Malaka, M. H., Wahyuni, \& Sahidin. (2019). Penapisan Fitokimia dan Uji Toksisitas Akut Ekstrak Metanol Beberapa Tanaman Obat Terhadap Larva Udang Artemia salina Leach. Pharmauho: Jurnal Farmasi, Sains, Dan Kesehatan, 5(2), 3034.

8. Muawanah, Ahmad, A., \& Natsir, H. (2016). Antioxidant Activity And Toxicity Polysaccharide Extract From Red Algae Eucheuma cottonii AND Eucheuma spinosum. 17(02), 15-23.

9. Sondakh, R. M., Posangi, J., \& Wowor, P. M. (2017). Uji Toksisitas Akut Ekstrak Spons Laut (Callyspongia aerizusa) terhadap Larva Artemia salina Leach dengan Metode Brine Shrimp
Lethality Test. Jurnal E-Biomedik, 5(2), 0-3.

10. Muaja, A. D., Koleangan, H. S. J., \& Runtuwene, M. R. J. (2013). Uji Toksisitas dengan Metode BSLT dan Analisis Kandungan Fitokimia Ekstrak Daun Soyogik (Saurauia bracteosa DC) dengan Metode Soxhletasi. Jurnal MIPA, 2(2), 115.

11. Sumihe, G., Liwas, D., \& Sekunder, M. (2013). Phytochemical Analysis and Determining Lc50 Value of Liwas Leave Methanol Extract. 1-4.

12. Pimentel Montanher, A. B., Pizzolatti, M. G., \& Costa Brighente, I. M. (2002). An application of the brine shrimp bioassay for general screening of Brazilian medicinal plants. Acta Farmaceutica Bonaerense, 21(3), 175-178.

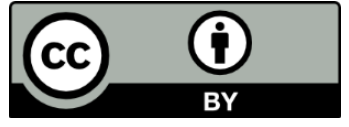

(C) 2020 by the authors; This article is an open access article distributed under the terms and conditions of the Creative Commons Attribution License (http://creativecommons.org/licenses/by/4.0/) 